\title{
WEBQUEST AS THE ANSWER \\ FOR ALTERING LEARNING/EDUCATIONAL NEEDS USING THE EXAMPLE OF LSP
}

\begin{abstract}
Aвstract. Kic-Drgas Joanna, WebQuest as the Answer for Altering Learning/Educational Needs Using the Example of LSP [WebQuest - odpowiedź na zmiany potrzeb edukacyjnych na przykładzie nauczania języka specjalistycznego]. Studia Edukacyjne nr 49, 2018, Poznań 2018, pp. 257-267. Adam Mickiewicz University Press. ISSN 1233-6688. DOI: 10.14746/se.2018.49.15

The paper aims to present the possibilities WebQuest gives in the educational context for recognising and catering to individual learners' needs. The focus of the article is on altering the learning conditions contributing to the deepening diversity of learners' needs. The use of the example of WebQuest as a teaching tool in LSP (Language for Specific Purposes) class for monitoring needs, together with a highly personalised teaching process, is analysed. The presented application of WebQuest fills in the gap in the individualisation of the teaching process.
\end{abstract}

Key words: education, WebQuest, new technology, LSP, learners' needs

Nowadays, education faces many challenges resulting from the rapidly changing environment and living conditions. On the one hand, the advancement of new technologies can be observed (like the broad application of the new media, the Internet, and the automatisation of many areas of life). The medial development remains not without a certain influence on the perception and shaping of the educational needs and expectations of learners. On the other hand, the intense specialisation and diversification of professional fields contributes to the creation of new educational goals. Consequently, new needs lead to the search for strategies and tools that may enable increased efficacy of the learning/teaching process.

The following paper aims to discuss the possibilities of the implementation of WebQuest as an educational tool using the example of LSP (Language 
for Specific Purposes). In order to analyse the set problem, the questions below are explored:

- What principles must be obeyed to introduce WebQuest as an educational tool?

- What are the advantages and drawbacks of using WebQuest as an educational tool?

- How can WebQuest be used for monitoring learners' needs?

The paper consists of three parts. In the first part, insight into the problem of changing educational needs and the necessity of developing new methods for responding to learners' expectations is given. In this part, the current state of the research on the topic is presented (p. 1).

In the second part of the paper, WebQuest is discussed as an educational tool, and a strong emphasis is placed on the advantages and drawbacks of using it in the educational process (p. 2).

In the last part of the paper, practical suggestions for using WebQuest to monitor learners' needs from both a short- and long-term perspective are provided (p. 3). The paper ends with conclusions and a discussion of prospective ways of developing the tool in different fields of education.

\section{The changing needs of learners}

Gutierrez, ${ }^{1}$ in her contribution on the new challenges of learning and teaching, states that "skills, knowledge, and needs of the student change". The main source of the mentioned changes is technology. According to Gutierrez (2014), technology is the trigger that creates learners' new needs and expectations; these are visible in the following shifts:

a) from individual to collaborative learning,

b) from passive to active learning,

c) from simple to differentiated instruction,

d) from one task to the phenomenon of multitasking.

The first paradigm refers to the possibilities technology offers in the processes of learning and teaching. No longer do time and place delineate the beginning and the end of the teaching/learning process. Nowadays, people living in different countries can join common classes and profit from mutual knowledge and experience. In addition, the ability to work collaboratively is highly appreciated at the workplace. "Rapidly changing context

${ }^{1}$ K. Gutierrez, Four Ways Technology Is Changing How People Learn, Shiftlearning, http:/ / info.shiftelearning.com/blog/bid/336775/Four-Ways-Technology-Is-Changing-How-People-Learn-Infographic, [access: 12.06.2016]. 
now requires training and education curricula that are fluid and dynamic, and continually responsive to volatile workplace environments and societal changes." 2

Behrens $^{3}$ states that learning needs have become more open, mobile, social and analytical, which must be considered in the way new knowledge is presented. Learners do not want to be spectators anymore; they want to participate actively in new undertakings and acquire knowledge while also sharing it with others, which again means that they need active ways of searching or researching knowledge.

Learners within any single 'class' are likely to have multiple needs to fulfill and not all of them aim toward the same learning goal. Each of them has his or her own set of concerns, agendas, abilities, values and priorities,

writes Gutierrez. ${ }^{4}$ Considering the multiplicity of different needs represented by the individual learners, a personalised approach to single learners is a necessity for guaranteeing educational success. ${ }^{5}$

However, criticism, the idea of multitasking in the context of multimedia, is an important part of education nowadays, especially among young people. ${ }^{6}$ It allows technology to be used to make the learning process more efficient and individualized.

\section{Learners' needs analysis}

People think and act differently, which results from their constructive perception of the surrounding reality. This diversity can also be observed in the learning process. Each learner starts learning with their individual previous knowledge or experience, which affects the speed and efficiency of the process. ${ }^{7}$

${ }^{2}$ M. Linehan, Work Based Learning - Graduating Through the Workplace, Cork 2008, p. 2.

3 S. Behrens, The Education-Technology Revolution Is Coming, USNews, http://www.usnews.com/opinion/articles/2013/03/01/the-education-technology-revolution-is-coming, [access: 12.06 .2016$]$.

4 K. Gutierrez, Four Ways Technology.

${ }^{5}$ J. Di Martino, J. Clarke, D. Wolk, Personalized Learning: Preparing High School Students to Create Their Futures, Lanham 2003.

${ }^{6}$ L.M. Carrier et al., Multitasking Across Generations: Multitasking Choices and Difficult Ratings in Three Generations of Americans, Computers in Human Behaviour, 2009, 25, p. 483-489.

7 J.G. Brooks, M.G. Brooks, In Search of Understanding: The Case for Constructivist Classrooms, Alexandria 1993; H. Siebert, Pädagogischer Konstruktivismus. Lernzentrierte Pädagogik in Schule und Erwachsenenbildung, Weinheim 2009. 
Apart from the mentioned factors, motivation, expectations and possible future practical use of the acquired material also play a vital role in the learning content.

The constructive approach lays foundations for the individualised process of acquiring knowledge, which again results in the scientific considerations that strongly emphasise need analysis as the first step in planning curriculum.

Need analysis is a subject discussed by many scientists. However, in the following paper, only a few chosen approaches to the subject are briefly described in order to show the complexity of the topic and the multidimensionality of the phenomenon of learners' needs:

- Richterich and Chancerel ${ }^{8}$ first describe an outline for the needs analysis and emphasise its main aims:

- Receiving initial information about the group;

- Designing and implementing the programme;

- Developing goals, objectives and content;

- Providing data for evaluating the existing programme.

The drawn considerations are written into a systemic approach that foresees the constant monitoring of learners' needs, beginning before the course (by examining information), and then analysed during the course by learners and by other institutions, such as the learners' place of work. ${ }^{9}$

- Hutchinson and Waters ${ }^{10}$ introduced a learning-centred approach to ESP that focuses on learner needs analysis. In the cited model, learner needs are approached from two directions. On the one hand, the focus is on the learning needs and on other target needs, defined as "what the learner has to do in the target situation". ${ }^{11}$ The latter are divided into three categories: necessities, lacks and wants, whereas:

a) Necessities are "what the learner has to know in order to function effectively in the target situation",;

b) Lacks are the gaps between what the learner knows and should know; ${ }^{13}$

c) Wants are "what the learners think they need". ${ }^{14}$

${ }^{8}$ R. Richterich, J-L. Chancelerel, Identifying the Needs of Adults Learning a Foreign Language, Oxford 1977.

${ }^{9}$ R.R. Jordan, English for Academic Purposes: A Guide and Resource Book for Teachers, Cambridge 1997.

${ }_{10}$ T. Hutchinson, A. Waters, English for Specific Purposes: A Learning-Centred Approach, Cambridge 1987.

11 Ibidem, p. 54.

${ }^{12}$ Ibidem, p. 55.

${ }^{13}$ Ibidem, p. 56.

${ }^{14}$ P. Nation, Designing and Improving a Language Course, Forum, 2000, 38, p. 2. 
Learner needs involve:

- Teaching and learning styles with which the learners are familiar;

- Appropriate learning and teaching methods;

- Knowledge of specialised content that teachers should know;

- Suitable instruction materials and study location;

- Time of study and status of ESP courses;

- Expectations about what learners should achieve in the course;

- Meaning of the courses for the learner.

- Berwick ${ }^{15}$ and Brindley ${ }^{16}$ contributed to developing the learner-centred approach to the needs analysis based on the three contexts of interpreting learners' needs: perceived vs. felt needs (whereas perceived needs are defined by learners and felt by experts); product (understood as language used in a certain communicative situation) vs. process-oriented interpretations (understood as the response to the individual needs); objective (estimated prior to the course) vs. subjective needs (formulated during the course) ${ }^{17}$

- Long ${ }^{18}$ highlights the importance of the needs analysis, without which educational success cannot be reached. Simultaneously, the scientist notices that the source of differences between the learner groups results from their expectations:

The combination of target language varieties, skills, lexicons, genres, registers, etc., that each of these or other groups needs varies greatly, however, meaning that language teaching using generic programs and materials, not designed with particular groups in mind, will be insufficient. ${ }^{19}$

In summary, the discussed approaches depict only a part of the research dedicated to the needs analysis; simultaneously, they show that scientists are still not united when it comes to defining and monitoring learners' needs. The potential discrepancies in their opinions result from the fact that needs are changing and do not constitute a stable value, and this is connected to different factors determining the learners' needs, as well as to the highly individual character of one's needs corresponding with previous knowledge, the present situation and potential situations in which the knowledge will be used.

The unsolved problem of measuring and defining learners' needs reflects on the methods used to present new knowledge that adequately lives up to expectations. In the next part of the paper, one of the methods that enables the constant monitoring of learners' needs, WebQuest, is presented.

${ }^{15}$ R. Berwick, Needs Assessment in Language Programming: From Theory to Practice, [in:] The Second Language Curriculum, Ed. R.K. Johnson, Cambridge 1989, p. 48-62.

${ }^{16}$ G. Brindley, The Role of Needs Analysis in Adult ESL Programme Design, [in:] Ibidem, p. 63-77.

${ }^{17}$ Ibidem.

${ }^{18}$ M.H. Long (ed.), Second Language Needs Analysis, Cambridge 2005, p. 2.

${ }^{19}$ Ibidem, p. 2. 


\section{WebQuest - the main principles of the method}

WebQuest was developed in 1995 by Dodge; the model introduced the integration of teaching and use of the Web based on an individualised quest for knowledge, enabling an introduction of the method at any grade level. When using the method, learners are faced with online resources with the aim of finding and internalising the concrete knowledge necessary for solving a given task. ${ }^{20}$

With WebQuest, learners "are exposed to the wide range of online sources, such as subject experts, directories of information, databases, current news, and all manner of interest groups", ${ }^{21}$ which develops critical evaluation and concluding skills.

WebQuest consists of the following components: ${ }^{22}$

1) Introductory information - Presents the main domain of activity and stimulates learners' interest in the subject. Form: varies; may be role play.

2) Main task - A detailed description of the aim of the task. Form: written.

3) Resources - This stage involves the presentation of the previewed resources, including both online (for example, Web pages) and offline materials (books), which can be useful for learners. Learners receive a list of suggested resources, but they may choose whether or not to use them in their research.

4) Process - This has the character of a very detailed guide involving technical suggestions or tips, including how to complete the task and present the results.

5) Advice - This involves practical suggestions, such as how to organize collected information. It may take the form of a checklist with action points or questions. An important feature of this part of the task is the time restriction. Learners completing the task are given a lot of autonomy, and the realisation of the separate stages should be completed in a limited amount of time in order to motivate and close certain phases of the task, as well as to monitor progress.

6) Evaluation - This is a very crucial part of the task, involving, on the one hand, feedback for the students on the quality and correctness of the task, and on the other hand, the possibility to interact and discuss the potential difficulties that occur during the realisation of the project.

7) Conclusion - This is the finishing stage of the task, stimulating learners concerning the potential usage of the received results in the future. Learners can place their results on a special page created by the teacher.

\footnotetext{
${ }^{20}$ L.M. Schwartz, K. Wiling, Computer Activities for the Cooperative Classroom, Ontario 2001.

${ }^{21}$ Ibidem, p. 104.

${ }^{22}$ Ibidem, p. 105.
} 
The benefits of using the method (divided into macro- and micro-) are noted by Zheng, Stucky, McAlack, Menchana and Stoddard. ${ }^{23}$

In terms of macro-level benefits, WebQuest is a tool allowing one "to organize chaotic resources, and help learners gain new knowledge through guided learning environment." ${ }^{24}$ Micro-level profits include critical thinking, knowledge application and developing social skills.

Dudeney ${ }^{25}$ points out five reasons that WebQuest should be used in the language classroom:

- requires no advanced technology for learners or teachers

- supports interaction among learners

- allows for interdisciplinary inquiry

- encourages the use of higher order skills

- motivates learners through authentic context

Benz ${ }^{26}$ however, added the development of intrinsic interest and the fact that WebQuest affects the real, vivid use of language in a natural context. The observation made by Benz is the starting point for the practical considerations made in the next part of the paper.

In opposition to the claims of the scientists cited above, March ${ }^{27}$ (2000) names some disadvantages of using WebQuest:

- It is time-consuming, especially when learners do not access at home;

- Distractions arise stemming from Web use;

- It requires a precisely formulated task in order to avoid confusing learners;

- WebQuest can be boring or can waste time when not suited to the acquired material.

The given arguments indicate the meaning of the exact considerations made before beginning WebQuest with learners, including formulating the task as the framework.

\section{Outline of the problem}

Language for specific purposes is becoming more and more popular in Poland as the result of growing specialisations, the establishment of interna-

${ }^{23}$ R. Zheng et al., WebQuest Learning as Perceived by Higher-Education Learners, TeachTrends, 2005, 49(40), p. 41-49.

${ }^{24}$ Ibidem, p. 41.

${ }^{25}$ G. Dudeney, The Internet and the Language Classroom. A Practical Guide for Teachers, Cambridge 2003.

${ }^{26}$ P. Benz, Webquests: A Constructivist Approach, Ac-Grendoble. http://www.ardecol. ac-grenoble.fr/english/tice/enwebquests.htm, [access: 20.06.2016].

27 T. March, The 3 Rs of WebQuests, Multimedia Schools Magazine, 2000, 7. 
tional contacts (along with the transfer of knowledge) and increasing requirements of potential employers regarding language skills.

The planning and conduction of the courses in the field of teaching language for specific purposes is a good example of the problems that occur as a result of the disparities of learners ${ }^{28}$ that were mentioned in the above parts of the text:

- highly heterogeneous target groups (differing, on the one hand, in the level of knowledge of the foreign language, and on the other hand, in the learning experience and subject-content knowledge),

- the different needs represented by the learners who attend the class at the beginning of the course,

- changing needs during the course.

An individual approach to learners is very hard to achieve due to time and financial constraints, both at commercial language courses and at university-level courses.

WebQuest is not a permanent solution to all of the named difficulties, but more of a half-way option, creating a personalised learning experience at the lowest cost possible. In the next part of the paper, the exemplary use of WebQuest for measuring learners' needs in LSP teaching is discussed.

\section{WebQuest as a tool for monitoring learners' needs}

Asunka $^{29}$ indicates the short- and long-term perspective of WebQuest, whereas:

- the short-term perspective relates to knowledge acquisition and integration, and refers to the initial stage of preparing the task,

- the long-term perspective shows a deeper analysis of the knowledge and its understanding, transformation and application, taking between one week and several months.

\section{Target group}

The target group of the presented WebQuest may be students of economy who are learning English for specific purposes, as well as philology students who are broadening their knowledge of specific vocabulary.

${ }^{28}$ For more on this subject, see J. Kic-Drgas, Studienbegleitender Deutschunterricht in Polen - Eine Bedarfsanalyse unter Studierenden der Technischen Universität Koszalin, Zeitschrift für interkulturelle Kommunikation, 2016, 21, p. 125-136.

${ }^{29}$ S. Asunka, Webquests: A Literature Review on Their Use to Foster Critical Thinking in Learners, TCColumbia, http://www.google.pl/url?sa=t\&rct=j\&q=\&esrc=s\&source=web\&c$\mathrm{d}=4 \&$ ved=0ahUKEwjllenomcjNAhVICZoKHQIsAyoQFgg4MAM\&url=http $\% 3 \mathrm{~A} \% 2 \mathrm{~F} \% 2 \mathrm{Fpock}-$ etknowledge.tc.columbia.edu \%2Fhome.php \%2Fviewfile \% 2Fdownload \%2F3321\&usg=AFQjCNH3U2_CPrwJ5SsYMjGHgxB65Seqfg, [access: 27.06.2016]. 
Aim

The main aim of WebQuest is to make students familiar with the specific vocabulary connected with the stock exchange. However, an additional function of WebQuest is to monitor learners' needs.

Possible tasks given to the students for WebQuest in the LSP class on stock exchange:

- Analyse company XYZ and its value on the stock exchange. Convince a partner to buy its shares. Prepare a visualised analysis.

- Prepare a short course for the stock-exchange laymen. Explain the main processes in the easiest possible form.

- Defining and monitoring learners' needs can take place during the following steps of the presented WebQuest: during short online sessions, as a blog or during a traditional class. Another possibility includes students' diaries.

\section{Short-term perspective}

\section{Introductory information}

Apart from presenting the usage of the information gained by completing certain tasks, the short reflexive part on the state of the knowledge of the given topic and expectations after the finished task can also be:

- "You are here" - What is your motivation to learn LSP (Language for Specific Purposes) about the stock exchange?

- What do you expect from the task?

- What do you already know about the stock exchange?

Short answers to the above questions make it possible to orientate learning towards the general needs of the participants.

\section{Main task}

In context of the "end product description", the conscious attitude of the students towards the knowledge gained also plays a main role:

- What do you expect to learn through the given task?

- Where can you use the acquired knowledge?

\section{Long-term perspective}

\section{Resources}

One of the aims of WebQuest is to develop critical thinking in the context of materials found on the Internet. Developing evaluation skills to assess the collected information with a more long-term perspective can be an aim in itself, as well as means to achieve another goal.

- Which of the mentioned resources was really valuable to you? Choose one and explain why.

- Which of the mentioned resources can you use in the future? 


\section{Process}

The process of preparing the "end result" can last a longer time, providing an opportunity to look at the acquired knowledge from a pragmatic perspective.

- Which stages of the process do you assess as being the most beneficial for your initial aims? Why?

- Have your learning needs changed during the process of completing the task? In what way?

\section{Evaluation}

A final evaluation of the process is essential to the success of monitoring learning needs and estimating further learning aims.

- How have you developed your skills through the given task?

- What are your learning needs and aims now?

\section{Conclusion}

The use of new technologies is apparent in diverse areas of life. One of the fields technology has found an application in is education, where the latest technology enables a broadening of teaching and learning opportunities. WebQuest is an example of a tool that develops learners' autonomy and allows for continuous monitoring of learners' progress. However, its function relates not only to enhancing cooperation skills, but also to creativity and focus on the preferred field, which contributes to strengthening learners' autonomy. Reflective considerations introduced in the following stages of the task realisation allow for meeting the changing needs and expectations of the participants, both from a long- and short-term perspective. The success of the disputed tool depends on how the task is explicitly framed and formulated, as well as on the criteria used in its evaluation.

WebQuest can be used in heterogeneous groups of learners with diverse interests and needs. The duration of the task connected with the process provides an opportunity to monitor learners' needs and adequately guide their development. WebQuest can be used in foreign language teaching, as well as in the field of teaching in general. Consequently, the tool is not only a source of multidimensional evolvement, but, most importantly, also draws an outline for the education of tomorrow based on its personalisation of the learning process.

\section{BIBLIOGRAPHY}

AsunkaS.,Webquest:A Literature Reviewon TheirUseto Foster Critical ThinkinginLearners, TCColumbia, http:/ / www.google.pl/url?sa=t\&rct=j\&q=\&esrc=s\&source=web\&cd=4\&ved 
=0ahUKEwjllenomcjNAhVICZoKHQIsAyoQFgg4MAM\&url=http\%3A\%2F\%2Fpocketknowledge.tc.columbia.edu \% 2Fhome.php \% 2 Fviewfile $\% 2$ F download\%2F3321\&usg=AFQjCNH3U2_CPrwJ5SsYMjGHgxB65Seqfg, [27.06.2016].

Behrens S., The Education-Technology Revolution Is Coming, USNews, http:/ / www.usnews. com/opinion/articles/2013/03/01/the-education-technology-revolution-is-coming, [access: 12.06.2016].

Benz P., Webquests, a Constructivist Approach, Ac-Grendoble, http:/ / www.ardecol.ac-grenoble.fr/english/tice/enwebquests.htm, [access: 20.06.2016].

Berwick R., Needs Assessment in Language Programming: From Theory to Practice, [in:] The Second Language Curriculum, Ed. R.K. Johnson, Cambridge 1989.

Brindley G., The Role of Needs Analysis in Adult ESL Programme Design, [in:] The Second Language Curriculum, Ed. R.K. Johnson, Cambridge 1989.

Brooks J.G., Brooks M.G., In Search of Understanding: The Case for Constructivist Classrooms, Alexandria 1993.

Carrier L.M., Cheever N.A., Rosen L.D., Benitez S., Chang J., Multitasking Across Generations: Multitasking Choices and Difficult Ratings in Three Generations of Americans, Computers in Human Behaviour, 2009, 25.

Di Martino J., Clarke J., Wolk D., Personalized Learning: Preparing High School Students to Create Their Futures, Lanham 2003.

Dudeney G., The Internet and the Language Classroom. A practical Guide for Teachers, Cambridge 2003.

Gutierrez K., Four Ways Technology Is Changing How People Learn, Shiftlearning, http:/ / info.shiftelearning.com/blog/bid/336775/Four-Ways-Technology-Is-Changing-How-People-Learn-Infographic, [access: 12.06.2016].

Hutchinson T., Waters A., English for Specific Purposes: A Learning-Centred Approach, Cambridge 1987.

Jordan R.R., English for Academic Purposes: A Guide and Resource Book for Teachers, Cambridge 1997.

Kic-Drgas J., Studienbegleitender Deutschunterricht in Polen - Eine Bedarfsanalyse unter Studierenden der Technischen Universität Koszalin [German for Specific Purposes in Poland - Need Analysis at the Koszalin University of Technology], Zeitschrift für interkulturelle Kommunikation [Journal of Intercultural Communication], 2016, 21.

Linehan M., Work Based Learning - Graduating Through the Workplace, Bishopstown, Cork 2008.

Long M.H. (ed.), Second Language Needs Analysis, Cambridge 2005.

March T., The 3 Rs of WebQuests, Multimedia Schools Magazine, 2000, 7.

Nation P., Designing and Improving a Language Course, Forum, 2000, 38.

Richterich R., Chancelerel J-L., Identifying the Needs of Adults Learning a Foreign Language, Oxford 1977.

Schwartz L.M., Wiling K., Computer Activities for the Cooperative Classroom, Ontario 2001.

Siebert H., Pädagogischer Konstruktivismus. Lernzentrierte Pädagogik in Schule und Erwachsenenbildung [Pedagogic Constructivism. Learner-Oriented Pedagogy at School and in Adult Education], Weinheim u.a 2009.

Zheng R., Stucky B., McAlack M., Menchana M., Stoddard S., WebQuest Learning as Perceived by Higher-Education Learners, TeachTrends, 2005, 49(40). 